\title{
Gustatory, salivary, and oral thermal responses to solutions of sodium chloride at four temperatures ${ }^{1}$
}

\author{
ROSE MARIE PANGBORN, ROSALIND B. CHRISP, AND LINDA L. BERTOLERO2 \\ UNIVERSITY OF CALIFORNIA, DAVIS
}

\begin{abstract}
Using eight highly trained Ss, sensitivity to near threshold levels of $\mathrm{NaCl}$ was significantly greater at solution temperatures of $22^{\circ}$ and $37^{\circ} \mathrm{C}$ than at $0^{\circ}$ or $55^{\circ} \mathrm{C}$. Perceived intensity increased linearly with concentration $10.04 \% 0.64 \%$ $\mathrm{NaCl)}$ at all four solution temperatures, with the two lower considered slightly more intense than the two higher temperatures. Biomodal distributions were obtained for hedonic judgments at all temperatures, with three $S s$ showing greater liking and five Ss showing greater disliking of increasing concentrations. Parotid salivary flow was inversely related to the taste sensitivity, i.e., significantly lower flow rates were obtained for the intermediate than for the hot or cold solutions, independent of salt content. When solution temperature was $0^{\circ} \mathrm{C}$, the minimum temperature of the oral cavity was $9^{\circ}-20^{\circ} \mathrm{C}$; when solution temperature was $55^{\circ} \mathrm{C}$, the maximum temperature of the oral cavity was $46^{\circ}-49^{\circ} \mathrm{C}$.
\end{abstract}

Over 100 years ago, Camerer (1869) reported that the salty taste of $\mathrm{NaCl}$ was most intense between $10^{\circ}$ and $20^{\circ} \mathrm{C}$, when $30-c c$ portions were placed in the mouth. Kiesow (1896) merely reduced the oral aliquot to $10 \mathrm{cc}$ and observed that all taste substances became more intense as the solution temperature was elevated. In an attempt to clarify this apparent discrepancy, Komoru (1921) irrigated the tongue with $200-500 \mathrm{cc}$ of solution and found that thresholds for $\mathrm{NaCl}$, sucrose, quinine, and tartaric acid were lower at $30^{\circ}$ and $40^{\circ} \mathrm{C}$, and higher at $10^{\circ}$ and $20^{\circ} \mathrm{C}$. Cinaglia (1916) further reduced the stimulus quantity to $1 \mathrm{cc}$, which was placed directly on the tongue, and observed no change in taste thresholds with solution temperatures at $17^{\circ}, 37^{\circ}$, and $50^{\circ} \mathrm{C}$ or in reaction times. The interpretation of reaction time data for stimuli at varying temperatures is problematic, especially since studies such as those by McFadden (1937) concluded that reaction time to the taste of $\mathrm{NaCl}$ was longer at $3^{\circ}, 15^{\circ}$, and $23^{\circ} \mathrm{C}$ than at $37^{\circ}$, $47^{\circ}$, and $52^{\circ} \mathrm{C}$, but was independent of the stimulus concentration.

Goudriaan (1930) presented stimuli via a Geschmackslupe which restricts the flow of solution to a specified region of the tongue and found that intensity of the taste of
$\mathrm{NaCl}$ decreased as solution temperature was raised as follows: $10^{\circ}, 18^{\circ}, 35^{\circ}, 40^{\circ}$, $50^{\circ} \mathrm{C}$. This seems consistent with thresholds for $\mathrm{NaCl}$ reported by Hahn (1936), which increased linearly across solution temperatures of $17^{\circ}, 22^{\circ}, 27^{\circ}$, $32^{\circ}, 37^{\circ}$, and $42^{\circ} \mathrm{C}$. How disappointing it is that neither very cold nor very hot solutions were included in this relatively well-controlled experiment. On the other hand, the results obtained by Scofield (1934) conflict, as average RLs to $\mathrm{NaCl}$ for seven trained $S$ s were lowest at $15^{\circ}, 23^{\circ}$, and $33^{\circ}$, highest at $37^{\circ}, 42^{\circ}, 47^{\circ}$, and $52^{\circ} \mathrm{C}$, and intermediate at $3^{\circ}$ and $9^{\circ} \mathrm{C}$. It is interesting that his highest threshold was at $37^{\circ} \mathrm{C}$, because subsequently he stated that warm solutions of $\mathrm{NaCl}$, especially near body temperature, were emetic for some individuals (Scofield, 1939).

Bringing the literature review up to the present fails to clarify the controversy. Gridgeman (1958) reported that four Ss had greater sensitivity to taste mixtures at $23^{\circ} \mathrm{C}$ than at $7^{\circ}$ or $37^{\circ} \mathrm{C}$, whereas Maurizi and Cimino (1961) found lower thresholds for $\mathrm{NaCl}$ for $12 \mathrm{Ss}$ at $35^{\circ}-40^{\circ} \mathrm{C}$ than at $5^{\circ}-20^{\circ} \mathrm{C}$. To add variety, Shimizu et al (1959) discovered that half the young females tested were more sensitive to sweet and salty stimuli at solution temperatures between $32^{\circ}$ and $38^{\circ} \mathrm{C}$ and less sensitive at $15^{\circ}$ and $55^{\circ} \mathrm{C}$, while the remaining half demonstrated decreasing sensitivity with increasing temperatures from $15^{\circ}$ to $55^{\circ} \mathrm{C}$.

Readers desiring even further documentation of conflicting observations can consult the comprehensive reviews by Sato (1967) and Laffort (1969).

The study reported herein was undertaken not so much to bring order out of the preceding chaos as to determine among the same experimental Ss (1) whether or not taste sensitivity, perceived intensity, and degree of liking for solutions of sodium chloride are temperature-dependent; (2) whether or not salivary secretion is altered by solution temperature; and (3) the extent to which the temperature of the mouth at the taste receptor site differs from that of the water bath during tasting of these solutions.

\section{METHOD \\ Gustatory Measurements}

Five female and four male $S s$ with extensive previous experience in psychophysical testing of gustatory stimuli participated. Throughout the 6-month study, each $S$ evaluated each variable an equal number of times, so that the three psychophysical methods used could be compared. Test sessions were held twice daily, 9:30-10:00 a.m. and 2:30-3:00 p.m., Monday through Friday. The test compound was sodium chloride of reagent grade purity dispersed in water distilled daily from unchlorinated tap water. Chemical analysis of the distilled water in our laboratory over a year's period showed from $0.84-2.2 \mathrm{ppm}$ total dissolved solids with only traces of mineral ions (0-0.2 me/L Na ${ }^{+}, \mathrm{Mg}^{++}$, or $\mathrm{CA}^{++}$, and $0-0.01 \mathrm{me} / \mathrm{L} \mathrm{Cl}^{-}, \mathrm{CO}_{3}-\mathrm{HCO}_{3}^{-}$, and $\mathrm{SO}_{4}^{--}$).

Solutions were presented in $10-\mathrm{ml}$ portions in 50-ml beakers submerged in a stainless steel temperature-regulated water bath. Test temperatures were $0^{\circ}, 22^{\circ}, 37^{\circ}$, and $55^{\circ} \mathrm{C}$, representing ice water, room temperature, body temperature, and as hot as could be tolerated without discomfort. Ss were instructed to take the entire $10-\mathrm{ml}$ into the mouth, hold it for $5 \mathrm{sec}$, expectorate, and continue to the next sample after $30 \mathrm{sec}$. Water at the same temperature as the test solutions was rovided for oral rinsing, and swallowing was not permitted. The three psychophysical methods were utilized in the following order: Paired presentation of near-threshold concentrations vs distilled water (Which sample is saltier?); single-sample presentation of eight suprathreshold concentrations $(0.04 \%-0.64 \% \mathrm{NaCl}, \mathrm{w} / \mathrm{v})$ for evaluation of perceived intensity $(0=$ not salty at all, $9=$ extremely salty); and single-sample presentation of the same eight suprathreshold concentrations for measurement of degree of liking ( 1 = dislike extremely, $9=$ like extremely). Within each session, a single temperature was evaluated, with temperatures randomized across the entire number of sessions.

Samples were presented in a completely randomized order, identified by two- and three-digit code numbers on the aluminum covers. All judging was done in individual partitioned booths maintained at $22^{\circ} \mathrm{C}$. Ss were informed of the identity of the samples immediately after testing, and furnished with cake or cookies as 
"rewards." The number of replications per sample per method are indicated in the captions for Figs. 2, 3, and 4.

\section{Salivary Measurements}

Two male and two female Ss, selected on the basis of ease of obtaining parotid saliva and their availability during 1 -h test sessions, participated in two tests. The first consisted of presentation of 12 samples of distilled water, at each of four temperatures in the following sequence: $22^{\circ}, 37^{\circ}, 0^{\circ}$, and $55^{\circ} \mathrm{C}$. The second followed an identical presentation procedure in which the stimulus consisted of solutions of sodium chloride at $750 \mathrm{ppm}$. Following the same protocol as described for the taste studies, Ss placed the entire contents of the beaker in the mouth $(10 \mathrm{ml})$, held it for $5 \mathrm{sec}$, and expectorated, repeating the procedure at $30-\mathrm{sec}$ intervals for a total of 12 samples (6 min). No oral rinsing was used between samples and swallowing was not permitted. Unstimulated resting levels of 6-min duration preceded and followed each series of solutions. Oral temperature was measured at the onset of each test run and following the resting level after the $22^{\circ}$ and $0^{\circ} \mathrm{C}$. If the $\mathrm{S}^{\prime}$ s temperature was below his starting point $\left(37^{\circ} \pm 0.5^{\circ} \mathrm{C}\right)$, he rinsed his mouth with water at $37^{\circ} \mathrm{C}$ so that he would begin each new series of solutions at the same oral temperature. Four sessions of this protocol were completed, with the results of the first considered as orientation and discarded.

Unilateral parotid saliva was collected at the same time of day from the same gland for each $S$, using a modified, stainless steel Carlson-Crittenden vacuum cap, which fits over Stenson's duct by simple suction (Shannon et al, 1962). The technique has been used effectively in similar studies in this laboratory (Pikielna et al, 1968; Pangborn, 1968). Ss were seated comfortably in individual, partitioned booths maintained at $22^{\circ} \mathrm{C}$ and were provided with light reading material to peruse during the resting periods.

\section{Oral Thermal Measurements}

Unilateral temperature recordings were made from a fixed location in the oral cavity-the inner surface of the first molar tooth, close to the lateral surface of the tongue where the majority of the taste buds are located. This was accomplished by making plaster impressions of the lower dentition of each $S$, shaping an acrylic piece approximately $3 \mathrm{~cm}$ long to fit over the front side teeth, in which the thermistor (Allied Electronic, Type GB $41 \mathrm{~J} 1$ ) could be stationed precisely. The thermistor detector formed one leg of a Wheatstone Bridge circuit in which the other legs had values as shown in Fig. 1. After imbedding in the acrylic holder, each thermistor was calibrated against known water temperatures, using a single-channel Leeds and Northrup Speedomax $H$ recorder with a chart speed of $30 \mathrm{in} . / \mathrm{h}$. The recorder had a full-scale sensitivity of $1 \mathrm{mV}$, which corresponded to a chart displacement of about $4.1 \mathrm{~mm} /{ }^{\circ} \mathrm{C}$. A calibration chart was constructed for each thermistor for converting recorder readings into degrees Centigrade.

Before each test run, the thermistor-acrylic holder piece was sterilized in a solution of $0.2 \%$ Zephiran chloride and rinsed in distilled water. The $S$ entered an individual, partitioned booth and placed the acrylic piece in his mouth, while the $E$ plugged it into the signal attenuator and activated the recorder chart, outside the view of the $S$. Testing of solutions commenced as soon as the mouth reached $37^{\circ} \pm 0.5^{\circ} \mathrm{C}$. Test samples were then introduced into the mouth using the "tasting" procedure described previously, i.e., an initial rinse, then $10 \mathrm{ml}$ of solution held in the mouth for $5 \mathrm{sec}$, expectoration, repeating the procedure at 30 -sec intervals for a total of 12 samples. At the termination of the run, the time required for the mouth to return to the initial starting temperature was recorded. Three replications plus an original trial run, which was discarded, were completed for each of five $S s$ at each solution temperature, $0^{\circ}$, $22^{\circ}, 37^{\circ}$, and $55^{\circ} \mathrm{C}$.

\section{RESULTS}

Influence of Solution Temperature on Taste Responses

Sensitivity. Unfortunately, a smooth-line function did not result when correct responses were plotted against increasing concentrations of sodium chloride (Fig. 2), probably because of the fleeting sensations at near-threshold concentrations, where both sweet and salty are reported. However, two distinct distributions of taste

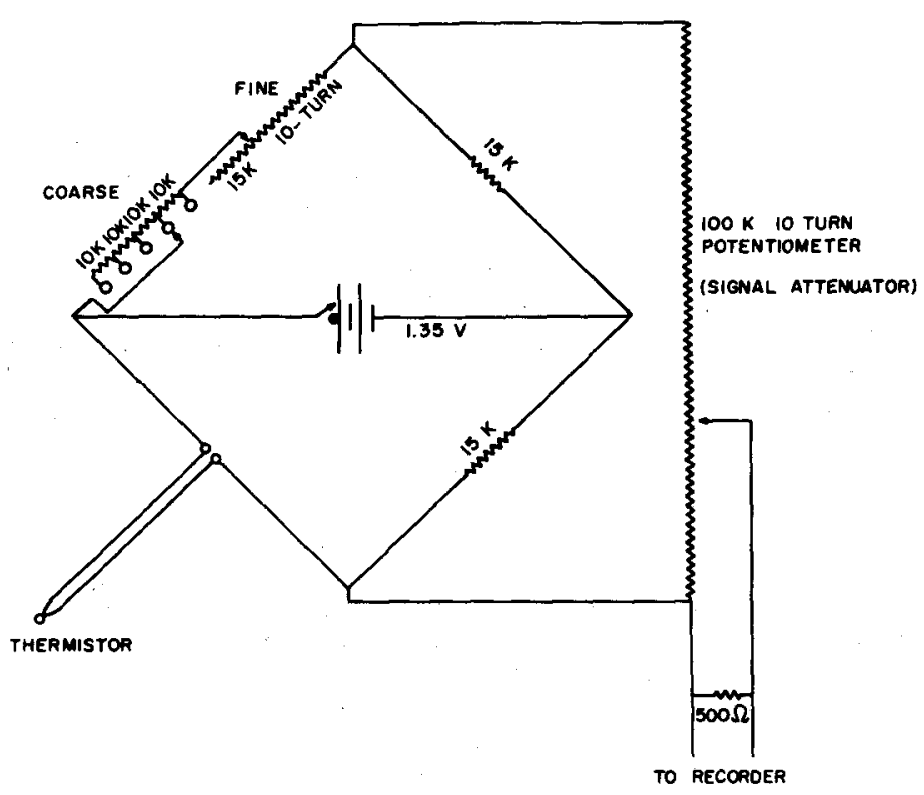

Fig. 1. Schematic diagram of bridge circuit used in the recording of oral temperature.

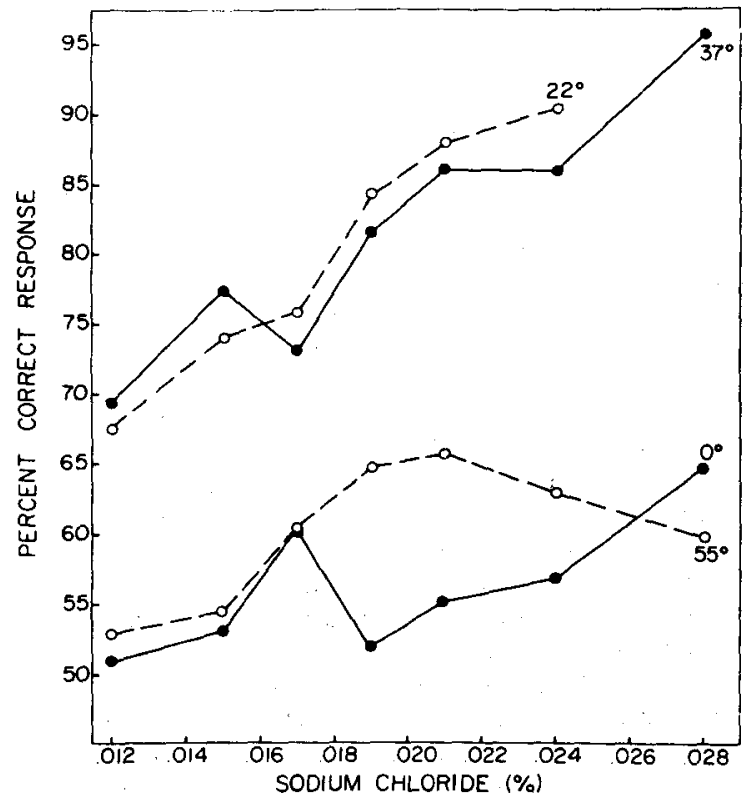

Fig. 2. Detection of near-threshold concentrations of sodium chloride at four solution temperatures. Each point represents an average of 216 replications ( 9 Ss $x 24$ trials). 


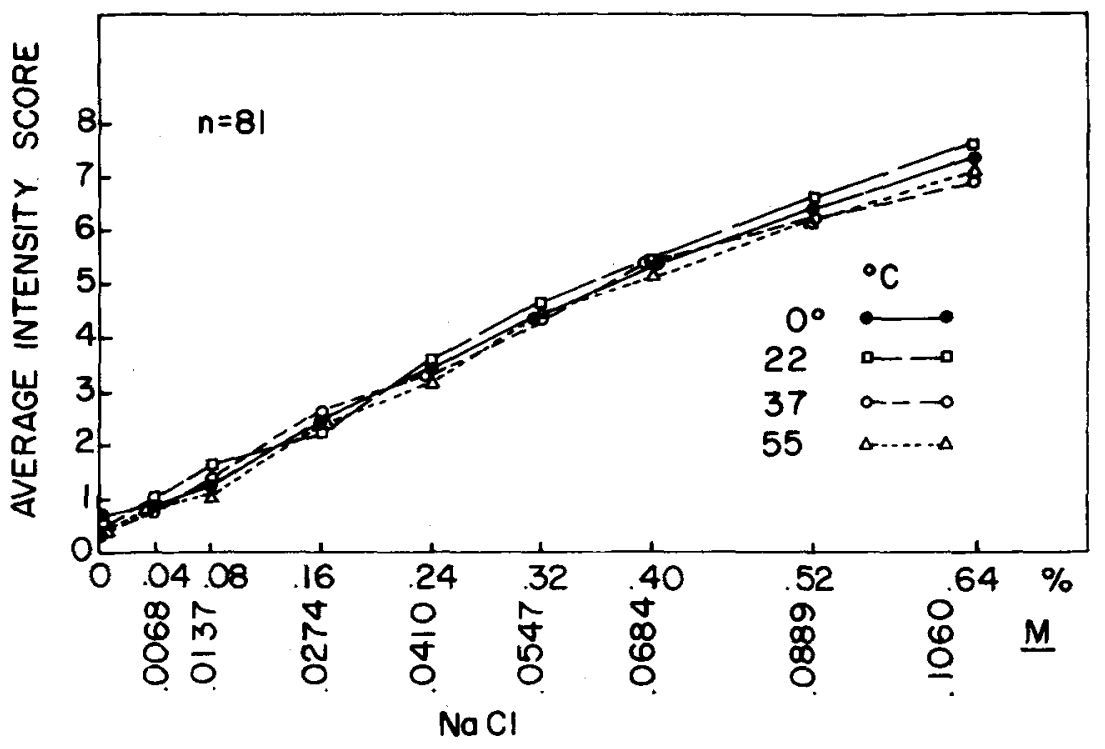

responses were obtained: significantly higher correct identification of samples at $22^{\circ}$ and $37^{\circ} \mathrm{C}$ than at the extremes of $0^{\circ}$ and $55^{\circ} \mathrm{C}\left(\chi^{2}=301.81\right)$. Since the S's task was to indicate the saltier samples compared to distilled water, these data probably are comparable to sensitivity thresholds reported in the literature: $0.0058 \%-0.468 \%$ with a median value of $0.058 \% \mathrm{NaCl}$ (Pfaffmann, 1959). If threshold is defined as $50 \%$ above chance, or $75 \%$ correct response in a paired comparison, the value of $0.017 \% \mathrm{NaCl}$ obtained for solutions at $22^{\circ} \mathrm{C}$ in this study falls within the reported literature threshold range, but is significantly lower than the reported median. Calculated sensitivity threshold at $22^{\circ} \mathrm{C}$ for individual Ss ranged from $0.010 \%$ to $0.030 \% \mathrm{NaCl}$. Owing to the unavilability of all the Ss for further testing, it was not possible to extend the concentrations of salt in the hot and cold series in order to calculate sensitivity thresholds for these temperatures. It is obvious from Fig. 2 , however, that sodium chloride is substantially more difficult to perceive in hot and cold solutions than at body temperature or at room temperature. These latter two distributions did not differ significantly.

Perceived intensity. Average intensity

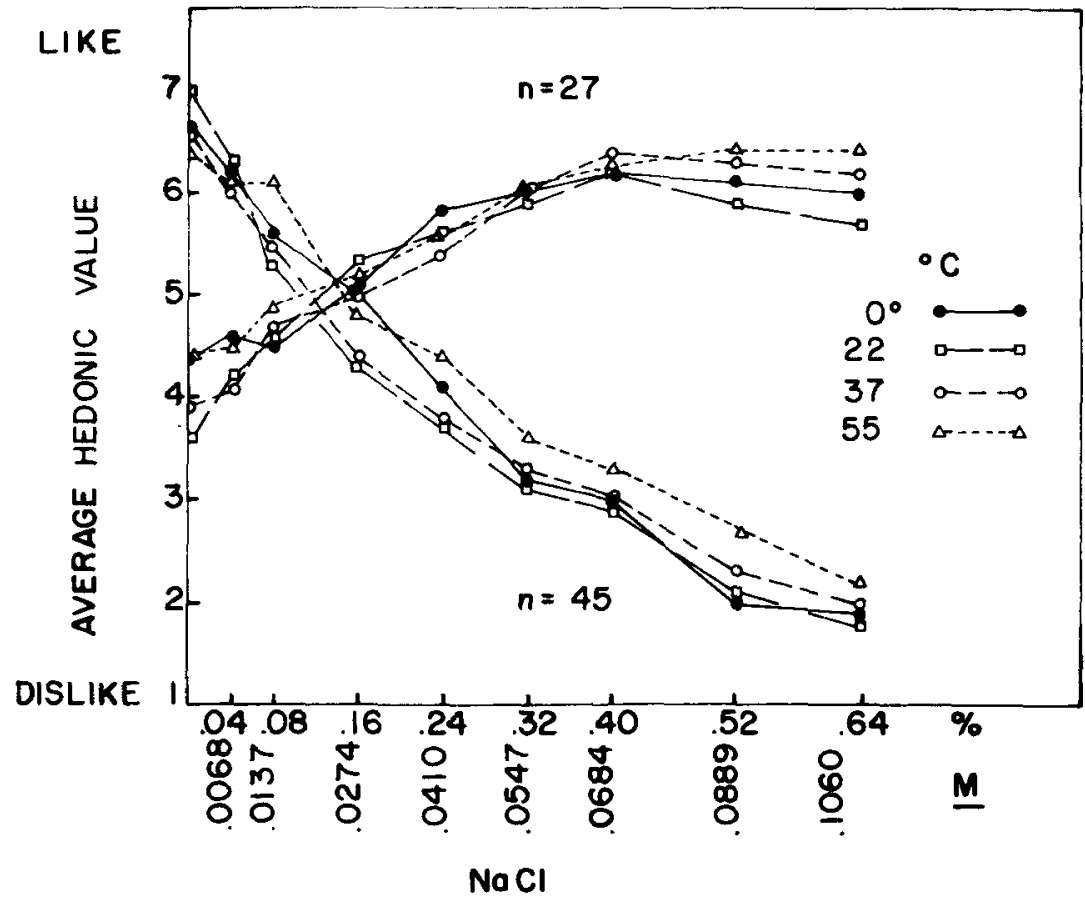

Fig. 3. Rated intensity of suprathreshold concentrations of sodium chloride at four solution temperatures. Each point represents an average of 81 replications ( 9 Ss $x 9$ trials).

scores of solutions from $0.04 \%$ to $0.64 \%$ $\mathrm{NaCl}$ at four temperatures formed a straight-line relationship with concentration (Fig. 3). Although there appears to be little difference among the lines for temperature, analysis of variance gave $F$ ratios significant at $p=0.001$ for both temperature and salt concentrations, but not for the interaction of the two. Overall intensity averages for the four temperatures were:

$$
\begin{array}{cccc}
55^{\circ} & 37^{\circ} & 0^{\circ} & 22^{\circ} \mathrm{C} \\
3.41 & 3.52 & 3.56 & 3.67 \\
\hline
\end{array}
$$

Values sharing an underline do not differ significantly according to Duncan's multiple range test. Both leniency and stringency was observed in the $\mathrm{Ss}^{\prime}$ use of the 10-point intensity scale, yet all essentially ranked the solutions, because of the manner of presentation of eight samples in randomized order within a temperature.

Degree of liking. Much to the investigators' surprise, degree of liking for the suprathreshold concentrations of salt resulted in a bimodal distribution (Fig. 4). Ss showed either increased liking or decreased liking with concentration, with none being neutral. Note that response to the distilled water blank also differed between the two groups. Inquiry among the Ss indicated that some thought that the salt improved the taste of distilled water, whereas others believed it decreased the water's desirability. However, in a subsequent paired comparison test in which there was no distilled water blank, the same Ss once again divided into two groups on the basis of their preference for sodium chloride. Using another predominantly salty compound, highly purified monosodium glutamate, a bimodal distribution of hedonic responses could not be demonstrated for these Ss. Another

Fig. 4. Degree of liking of suprathreshold concentrations of sodium chloride at four solution temperatures, expressed on a 9-point scale where $1=$ dislike extremely, $5=$ neither like nor dislike, and $9=$ like extremely. Three Ss demonstrated increased liking ( $3 \mathrm{Ss} x$ 9 trials) and five Ss demonstrated decreased liking (5 Ss $x 9$ trials) with increasing concentration. 


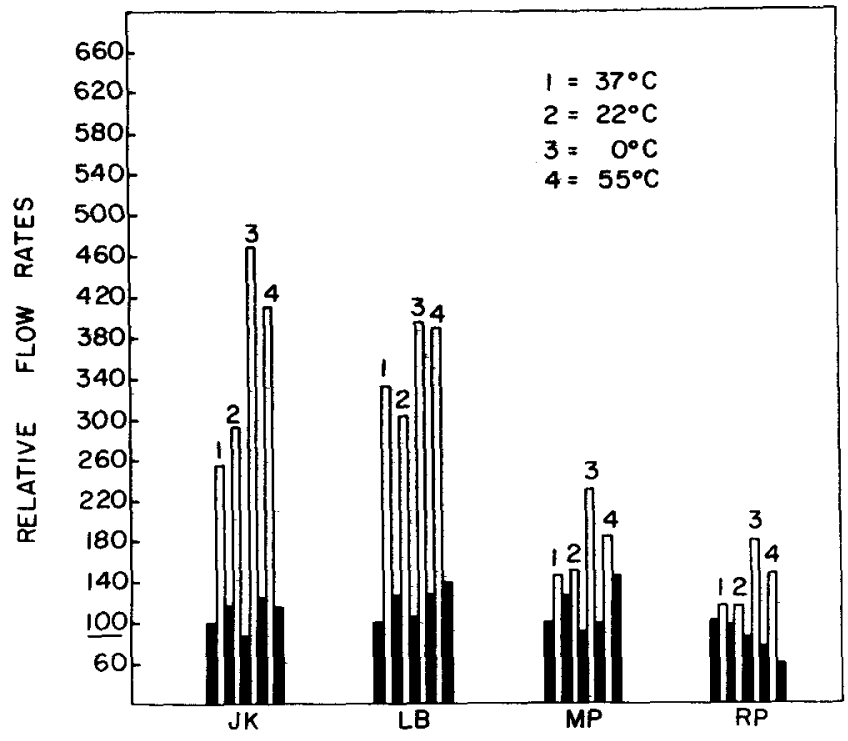

Fig. 5. Parotid salivary flow from four Ss stimulated by distilled water at four temperatures. Shaded bars represent unstimulated resting levels. Each value is the average of three determinations.

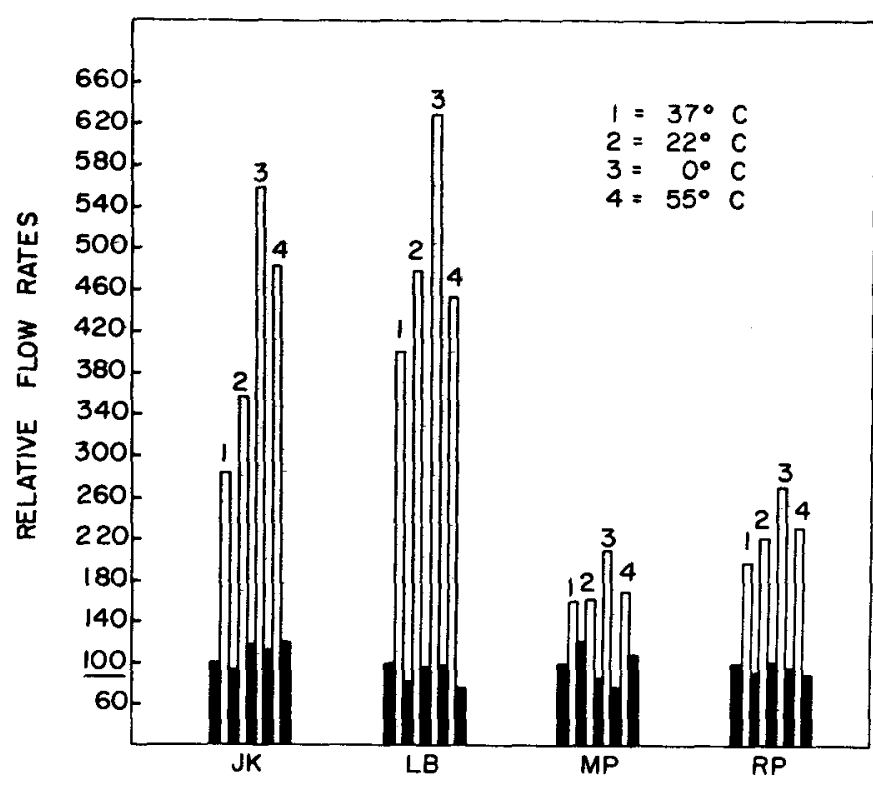

Fig. 6. Parotid salivary flow from four Ss stimulated by solutions of $750 \mathrm{ppm}$ sodium chloride at four temperatures. Shaded bars represent unstimulated resting levels. Each value is the average of three determinations. group of Ss demonstrated three types of distributions of hedonic response to an even wider range of sodium chloride as well as sucrose concentrations: increasing, decreasing, and increasing up to an intermediate point after which degree of liking decreased. ${ }^{3}$ Similar results had been obtained previously by Ekman and Åkesson (1964) and by Engen et al (1961).

Analysis of variance indicated highly significant differences between the two groups, among the concentrations, among the temperatures, and the Group by Concentration interaction, but not for the Group by Temperature or Concentration by Temperature interactions. The overall average hedonic values for temperature were:

$$
\begin{array}{lccc}
55^{\circ} & 0^{\circ} & 37^{\circ} & 22^{\circ} \mathrm{C} \\
4.83 & 4.66 & 4.57 & 4.50 \\
\hline
\end{array}
$$

Values sharing an underline do not differ significantly. Note that this order corresponds roughly to the sequence of intensity scores.

\section{Influence of Solution Temperature on Parotid Flow}

For the data plotted in Figs. 5 and 6, the initial unstimulated resting levels for each $S$ were converted to 100 , so that the remaining values could be expressed as relative flow rates, and are indicative of deviations from baseline levels. It is immediately apparent that the four Ss differed in the magnitude, but not in the direction, of their responses across the four temperatures, with the addition of $\mathrm{NaCl}$ inducing slightly higher relative flow rates within the same pattern. The actual overall average flow rates in terms of $\mathrm{ml} / \mathrm{min}$ for 12 determinations are shown in Table 1 . Significantly lower flow rates were obtained for the intermediate than for the hot and cold solutions, which is inversely related to the sensitivity data discussed in conjunction with Fig. 2.

Note that plotting flow rates in relative terms in Fig. 6 gives the impression that the $\mathrm{NaCl}$ at $750 \mathrm{ppm}$ induced more salivation than the distilled water (Fig. 5), whereas the absolute values in Table 1 show that flow rates are generally lower for salt than for water stimuli. Despite this apparent discrepancy, the authors felt the relative rates were more meaningful, as they are calibrated against each day's corresponding baselines. Furthermore, the water and salt studies were conducted a week apart. Individual Ss gave initial resting levels ranging from 0.072 to $0.133 \mathrm{ml} / \mathrm{min}$.

\section{Influence of Solution Temperature on Oral} Temperature

When Ss followed the exact timed tasting procedure as described for the in

\begin{tabular}{lcccccc}
\multicolumn{7}{c}{ Parotid Flow in Ml/Min } \\
\hline Stimulus & $\begin{array}{c}\text { Initial } \\
\text { Resting }\end{array}$ & 0 Deg & 22 Deg & 37 Deg & 55 Deg C & $\begin{array}{c}\text { Final } \\
\text { Resting }\end{array}$ \\
\hline $\mathrm{H}_{2} \mathrm{O}$ & 0.095 & 0.301 & 0.208 & 0.208 & 0.270 & 0.113 \\
$\mathrm{NaCl}$ & 0.073 & 0.298 & 0.222 & 0.189 & 0.236 & 0.071 \\
Average & 0.084 & 0.299 & 0.215 & 0.198 & 0.253 & 0.092 \\
\hline
\end{tabular}

gustatory experiments, oral temperature varied in the manner shown in Figs. 7 and 8 . The first point labeled $R$ was caused by the initial rinsing of the mouth with approximately $10 \mathrm{ml}$ of distilled water at the same temperature as the test solutions. The 12 minimum temperatures (Fig. 7) and the maximum temperatures (Fig. 8) correspond to the 12 solutions introduced into the mouth at $30-\mathrm{sec}$ intervals. The irregular peaks following these 12 points were caused by the oral rinsing procedure. When solution temperature was $0^{\circ} \mathrm{C}$, the minimum temperature of the oral cavity for this $\mathrm{S}$ was $14^{\circ} \mathrm{C}$, and when solution temperature was $55^{\circ} \mathrm{C}$, the maximum temperature of the oral cavity was $48^{\circ} \mathrm{C}$. Note that the temperature to which the mouth returns between stimuli changed gradually with subsequent samples, with a general descending trend for the $0^{\circ} \mathrm{C}$ solutions and a gradual ascending trend up to the fourth stimulus for the $55^{\circ} \mathrm{C}$ solutions. A total of $10 \mathrm{~min}$ was required for the mouth to return to $37^{\circ} \mathrm{C}$ with the cold solutions and $6 \mathrm{~min}$ with the hot solutions.

Figures 9-12 depict a simplified plot of minimum and maximum oral temperatures for the five $S s$ corresponding to introducing 12 solutions into the mouth at at nal 113 0.092 


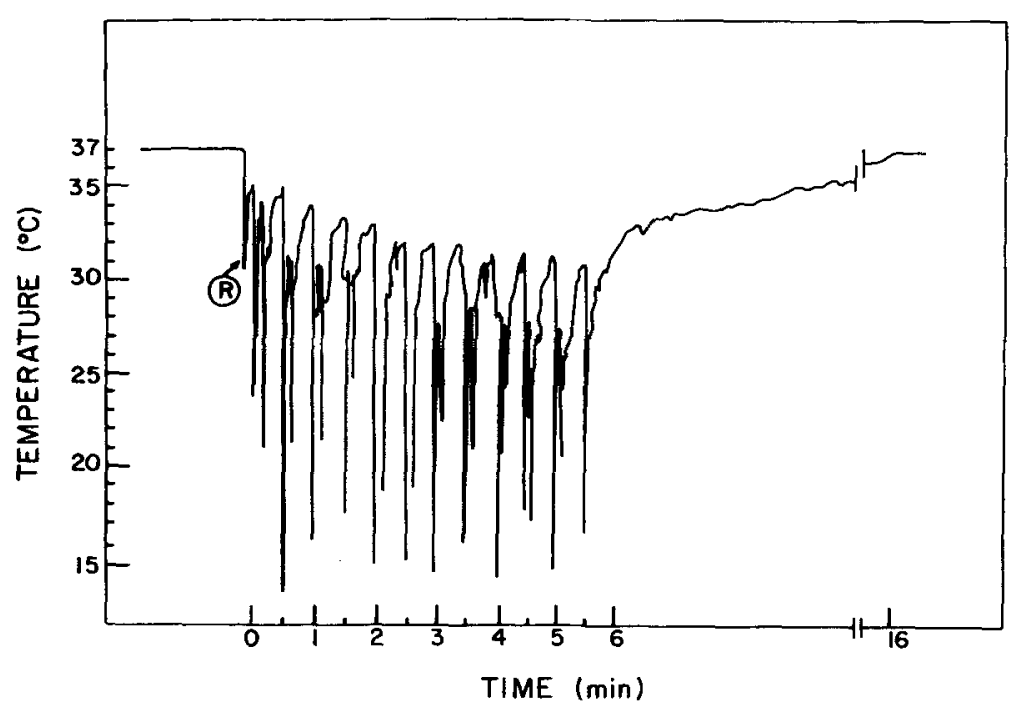

30-sec intervals. Differences among Ss are immediately apparent in all but Fig. 11, where the points simply represent opening and closing of the mouth to introduce the solutions at $37^{\circ} \mathrm{C}$. The second $\mathrm{S}, \mathrm{JB}$, showed the least and RP the greatest range from high to low oral temperatures. On the suspicion that placement of the thermistor opposite the first molar may position it at varying distances from the front of the mouth, measurements were made of the distance from the biting edge of the front incisors to the thermistor, as follows: $\mathrm{LB}=22 \mathrm{~mm}, \mathrm{JB}=35 \mathrm{~mm}, \mathrm{RC}=15 \mathrm{~mm}$, $\mathrm{RP}=31 \mathrm{~mm}$, and $\mathrm{IT}=29 \mathrm{~mm}$. These distances do not explain the differences in oral temperature among the Ss. When the thermistor was moved back to $41 \mathrm{~mm}$ for LB, the minimum temperature recorded when solutions at $0^{\circ} \mathrm{C}$ were introduced was $27.5^{\circ} \mathrm{C}$, compared to a low of $12.3^{\circ} \mathrm{C}$ in the previous position. Therefore, if the mouth temperature can change as much as $15^{\circ} \mathrm{C}$ as solutions at $0^{\circ} \mathrm{C}$ travel $9 \mathrm{~mm}$, thermistor position relative to the mouth opening is indeed important within a $S$ if not among Ss.

It can be seen in Figs. 9 and 10 that mouth temperature continued to decrease with subsequent samples up to the sixth or seventh stimulus. Conversely, for the hot waters, the mouth temperature continued to increase up to the fifth or sixth stimulus. For each temperature, a variable length of time was required by each $S$ for oral temperature to return to the initial value.

Fig. 8. Representative recording from the interior of the left first molar of $S$ LB when "tasting" distilled water at $55^{\circ} \mathrm{C}$, following same procedure described for Fig. 7.
Fig. 7. Representative recording from the interior of the left first molar of S LB when "tasting" distilled water at $0^{\circ} \mathrm{C}$. S placed $10 \mathrm{ml}$ water in mouth, "tasted" with gentle tongue movements for $5 \mathrm{sec}$, expectorated, and repeated procedure at $30-\mathrm{sec}$ intervals for $6 \mathrm{~min}$. $R=$ initial rinsing of oral cavity with approximately $10 \mathrm{ml}$ water.

bean pureé, while the other half responded exactly the opposite. It might be relevant in subsequent studies to pursue in depth the Ss' exact reaction to the taste of distilled water and/or the control sample per se, as well as their interpretation of the sensation of saltines. Their frame of reference might be important, e.g., whether solutions represent simple model systems or drinking water. Finally, the role of both the amount and the composition of an individual's saliva cannot be overlooked, as pointed out for sodium chloride by McBurney and Pfaffmann (1963) and even earlier for acids by Cragg (1937).

The agreement of the sensitivity data of Fig. 2 with neural responses reported by Sato (1967) merits comment, as he observed maximum response to $0.1 \mathrm{M} \mathrm{NaCl}$ in the chorda tympani at $30^{\circ} \mathrm{C}$ with significant drop-offs toward $10^{\circ}$ and $45^{\circ} \mathrm{C}$. Although it seems reasonable to us that extremes in hot or cold would interfere with gustatory perception, we hesitate to agree with Sato's inference that if maximum neural response for cats and rats is obtained at $30^{\circ} \mathrm{C}$ or tongue temperature, then intensity of the taste sensation also should be greatest at tongue temperature. This was not observed for solutions at $37^{\circ} \mathrm{C}$ in our studies, but it is acknowledged that the method of judging intensities within, rather than among, the temperatures might have prevented the finding of more pronounced differences.

The salivary responses depicted in Figs.

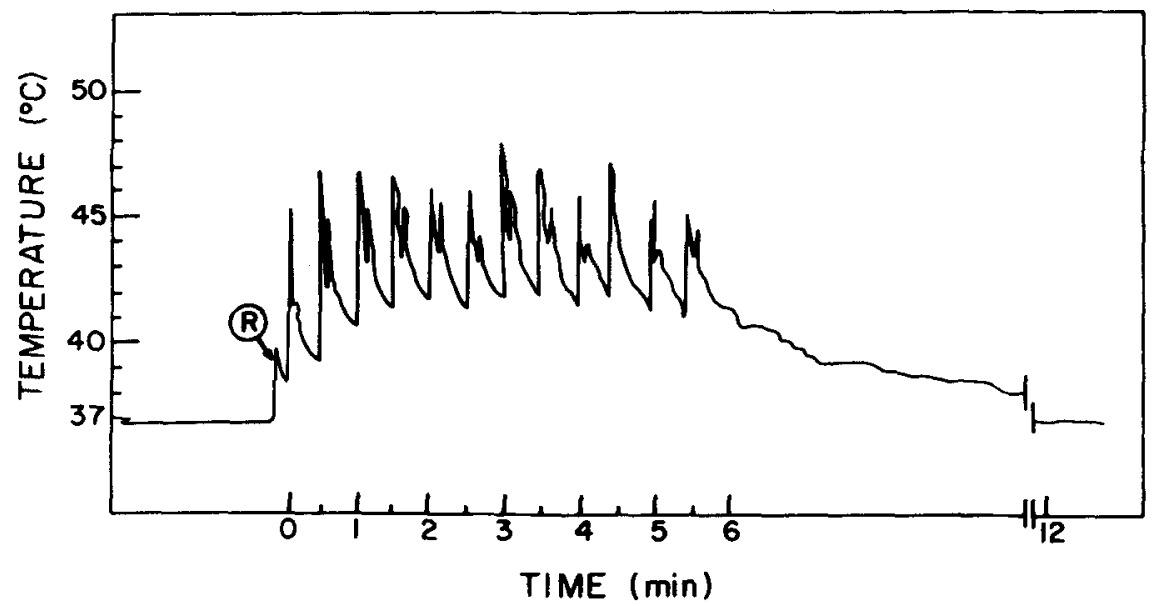




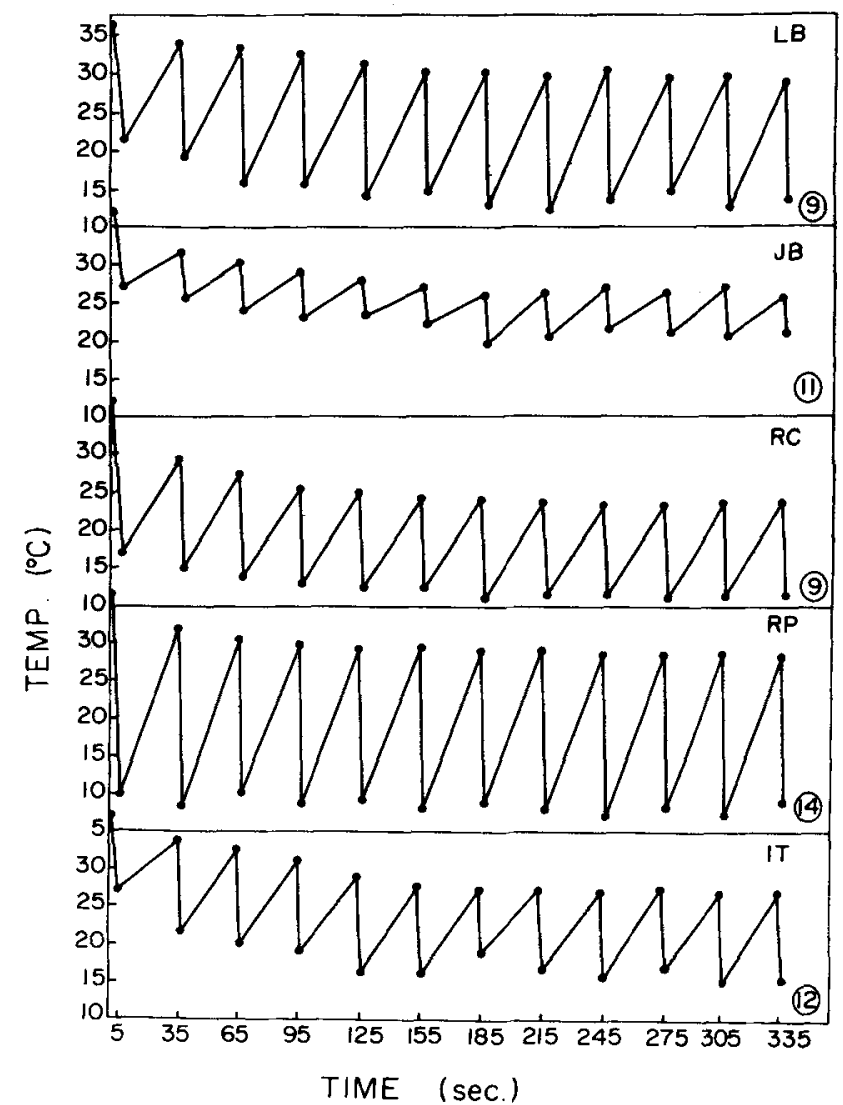

Fig. 9. Plot of minimum and maximum oral temperatures from the interior of the first molar of five Ss when "tasting" distilled water at $0^{\circ} \mathrm{C}$. $S$ placed $10 \mathrm{ml}$ in mouth, retained it for $5 \mathrm{sec}$, expectorated, and repeated procedure at 30 -sec intervals for $6 \mathrm{~min}$. Circled numbers on the right indicate the number of minutes required for the mouth to return to the starting oral temperature. Each value is the average of three determinations.

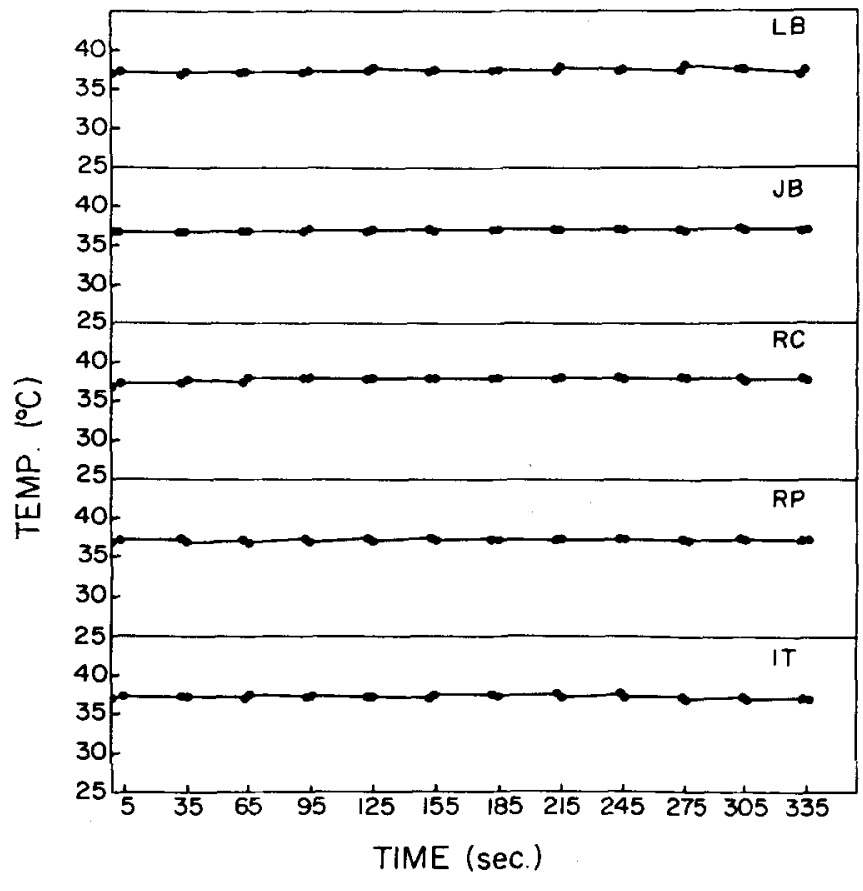

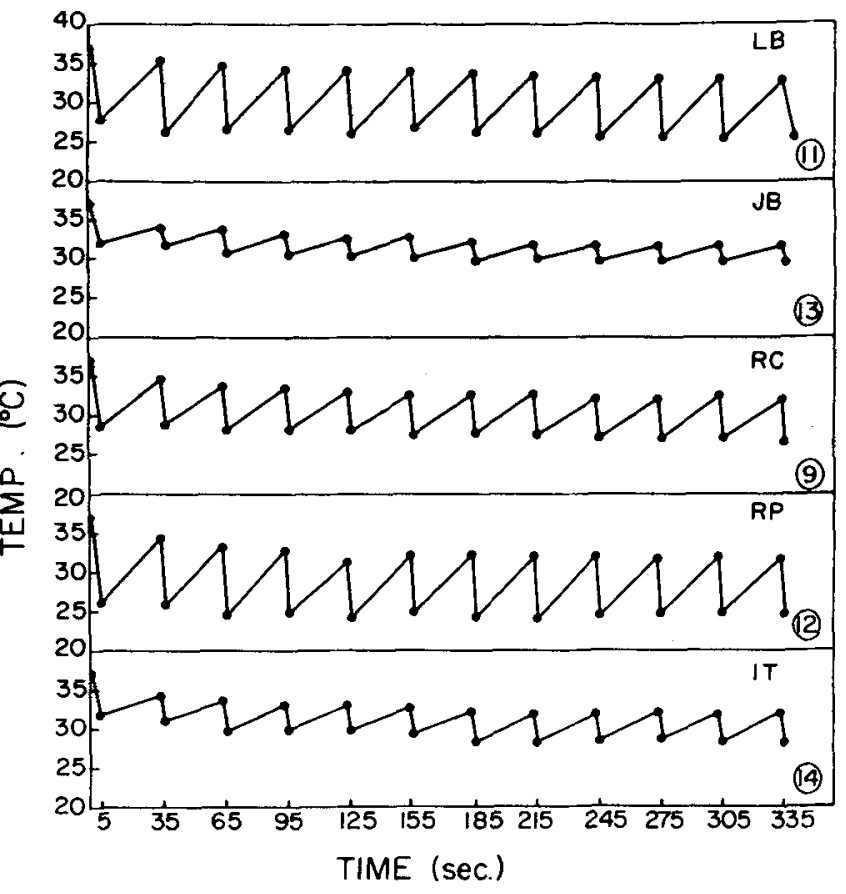

Fig. 10. Plot of minimum and maximum oral temperatures when "tasting" distilled water at $22^{\circ} \mathrm{C}$. Procedure same as described in Fig. 9.

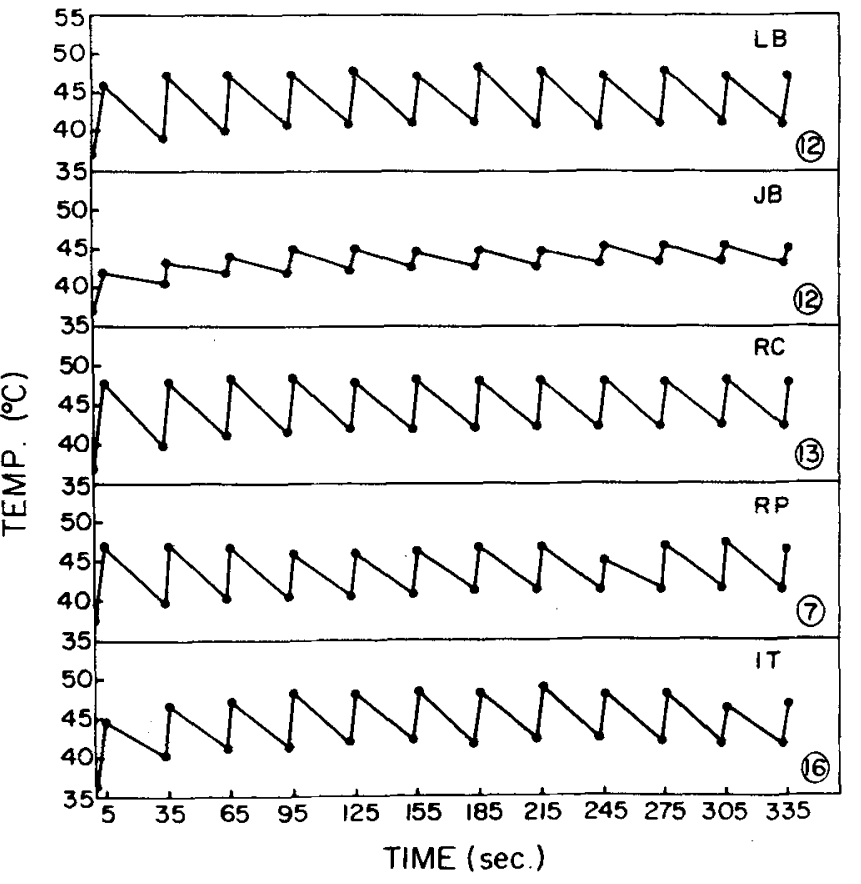

Fig. 11. (Left) Plot of minimum and maximum oral temperatures when "tasting" distilled water at $37^{\circ} \mathrm{C}$. Procedure same as described in Fig. 9.

Fig. 12. (Above) Plot of minimum and maximum oral temperatures when "tasting" distilled water at $55^{\circ} \mathrm{C}$. Procedure same as described in Fig. 9. 
5 and 6 , where more saliva is secreted at hot and at cold solution temperatures, suggest that this may be a compensation for the thermal deviation from normal mouth temperature. The nearest precedent that we could uncover in the literature is the study by Laurenzi (1925) who found that water at $5^{\circ}-6^{\circ} \mathrm{C}$ and as hot as tolerable produced no appreciable action from the parotid in himself and "several" colleagues. Using a unique procedure, Dorodnitsina (1937) started his experiments at $17^{\circ}$ to $23^{\circ} \mathrm{C}$, then transferred his $\mathrm{Ss}$ to a heated room $\left(45^{\circ}-55^{\circ} \mathrm{C}\right)$, to a refrigerator at $8^{\circ} \mathrm{C}$, or outdoors at $-3^{\circ}$ to $+3^{\circ} \mathrm{C}$. Cooling increased secretion from all salivary glands, especially the parotid, but heating produced a biphasic response-one group of Ss showed increased and the other decreased salivation. Interestingly, higher viscosities were measured in saliva collected at higher temperatures than at lower temperatures. The methodological procedure of moving the Ss bodily into varying thermal environments remains to be repeated.

Recording thermal changes in the oral cavity during simulated "tasting" experiments demonstrated the rapidity with which the mouth equilibrates the 10-ml aliquot, with continuous cooling or heating with subsequent samples. Inspection of the sensory responses failed to show that this decrease or increase in oral temperature changed sensitivity from the onset to the termination of the 12-sample series. It would seem somewhat erroneous to report sensory data in terms of the temperature of the water bath, when there is such a discrepancy with the temperature at the receptor site. On the other hand, reporting the responses as a function of thermal changes in only one part of the mouth could be equally incomplete. It would be most interesting to record from several oral positions simultaneously, as close to the gustatory receptors as possible. Dr. A. Marcström (1967) performed a most intriguing experiment on himself by attaching a thermocouple upon a spring to the palate by means of a plastic suction disc. Liquids were poured directly upon the tongue and since a nose clamp was used to eliminate olfaction, breathed air passed over the tongue in both directions. When solution temperatures were $20.4^{\circ}$ and $36.9^{\circ} \mathrm{C}$, respectively, temperature at the epithelial surface of the tongue averaged $27^{\circ}$ and $35^{\circ} \mathrm{C}$. He too noted that oral temperature dropped or rose slowly in the course of the experiment without reaching the temperature of the solution. Since the dorsum of the tongue is nearly devoid of gustatory receptors, it should be more desirable to record from the sides.

For those investigators working with solutions presented at room temperature, there is considerable consolation to be derived from the present results that sensitivity was highest, intensity was highest, parotid salivary flow was lower, and oral temperature did not deviate too widely at $22^{\circ} \mathrm{C}$. Beware generalizing to degree of liking, because hedonic response was lowest at $22^{\circ} \mathrm{C}$.

\section{REFERENCES}

CAMERER, W. Die Grenzen der Schmeckbarkeit von Chlornatrium in wassriger Losung. Pflugers Archiv für die Gesamte Physiologie des Menschen und der Tiere, 1869, 2, 322-329.

ChINAGLIA, L. De l'influence qu'exerce la température sur la sensibilité gustative. Archives Italiennes de Biologie, 1915, 63, $401-409$.

CRAGG, L. H. The relation between sourness and the $\mathrm{pH}$ of the saliva. Transactions of the Royal Society of Canada, 1937, 31, 7-13.

DORODNITSINA, A. A. Vliianie okhlazhdeniia i nagrevaniia na bezuslovnye sliunnye refleksy cheloveka. Fiziologicheskii Zhurnal SSSR, 1937, 23, 111-116.

EKMAN, G., \& ÁKESSON, C. Saltiness, sweetness, and preference. A study of quantitative relations in individual subjects Reports, Psychology Laboratory, University of Stockholm, 1964, 177, 1-13.

ENGEN, T., McBURNEY, D. H., \& PFAFFMANN, $C$. The sensory and motivating properties of the sense of taste, cited by $C$. Pfaffmann in M. R. Jones (Ed.), Nebraska Symposium on Motivation. Lincoln: University of Nebraska Press, 1961. Pp. 71-110.

GOUDRIAAN, J. C. Über den Einfluss der Temperatur auf die Geschmacksempfindung. Archives Neerlandaises de Physiologie de 1'Homme et des Animaux, 1930, 15, 253-282.

GRIDGEMAN, N. T. Psychophysical bias in taste testing by pair comparison, with special reference to position and temperature. Food Research, 1958, 23, 217-220.

HAHN, H. Über die Ursache der Geschmacksempfindung. Klinische Wochenschrift, 1936, 15, 933-935.

KIESOW, F. Beiträge zur physiologischen Psychologie des Geschmackssinnes. Philosophische Studien, 1896, 12, 255-278, 464-473.

KOMURO, K. Le sens du goùt a-t-ii un coefficient de température? Archives Neerlandaises de Physiologie, 1921, 5, 572-579.

LAFFORT, P. Température et qualités organoleptiques. Annales Nutr. Aliment, 1969 , 23, 63-77.

LAURENZI, V. de. Sulla secrezione parotidea nell' uomo provocata da diversi fattori periferici. Atti della Accademia Nazionale dei lincei, 1925, 6, 599-602.
MARCSTRÖM, A. Studies on the connection between physico-chemical properties and stimulating abilities of some sweet and bitter compounds. Arkiv für Zoologi, 1967, 19, 421-535.

MAURIZI, M., \& CIMINO, A. L'influenza delle variazioni termiche sulla sensibilità gustativa. Boll. Mallattie Orecchio Gola, Naso, 1961, 79, 626-634.

MCBURNEY, D. H., \& PFAFFMANN, C. Gustatory adaptation to saliva and sodium chloride. Journal of Experimental Psychology, 1963, 65, 523-529.

McFADDEN, H. B. The influence of temperature and solution concentration on reaction time to taste stimuli (sodium chloride). Journal of Psychology, 1937, 4, 349-363.

PANGBORN, R. M., \& TRAUBUE, I. M. Detection and apparent taste intensity of salt-acid mixtures in two media. Perception \& Psychophysics, 1967, 2, 503-509.

PANGBORN, R. M. Parotid flow stimulated by the sight, feel, and odor of lemon. Perceptual \& Motor Skills, 1968, 27, 1340-1342.

PIKIELNA, N. B., PANGBORN, R. M., \& SHANNON, I. L. Effect of cigarette smoking on parotid secretion. Archives of Environmental Health, 1968, 17, 731-738.

PFAFFMANN, C. The sense of taste. In J. Field (Ed.), Handbook of physiology-neurology 1. Washington, D.C: American Physiological Society, 1959. Pp. 507-533.

SATO, M. Gustatory response as a temperature-dependent process. In W. D. Neff (Ed.), Contributions to sensory physiology. New York: Academic Press, 1967. Pp. 223-251.

SCOFIELD, E. H. Studies in taste: The effect of solution temperature on the stimulus threshold of sodium chloride. Unpublished MA thesis, The Ohio State University, 1934.

SCOFIELD, E. H. An experimental study of some factors influencing the determination of gustatory thresholds. PhD dissertation, The Ohio State University, 1939.

SHANNON, I. L., PRIGMORE, J. R., \& CHAUNCEY, H. H. Modified Carlson-Crittenden device for the collection of parotid fluid. Journal of Dental Research, $1962,41,778-783$.

SHIMIZU, M., YANASE, T., \& HIGASHIHIRA $K$. Relations between gustatory sense and temperature of drinks. Kaseigaku Kenkyu, 1959, 6, 26-28.

\section{NOTES}

1. This investigation was supported in part by Public Health Service Research Grant UI-0016? from the National Center for Urban and Industrial Health. Appreciation is extended to Professor W. G. Jennings for advice and assistance on the temperature recording measurements. The technical assistance of Mrs. Ida M. Trabue and participation of the experimental subjects is gratefully acknowledged.

2. Address: Department of Food Science and Technology, University of California, Davis, California 95616.

3. Pangborn, R. M. Unpublished data, 1969.

(Accepted for publication December 3, 1969.) 